DOI: https://doi.org/10.32839/2304-5809/2020-78.1-19

UDC 378.091.275:811.111

Poplavska Lyudmyla, Ostrovska Olexandra

Ivan Franko National University of Lviv

\title{
TESTING IN LANGUAGE TEACHING: CLASSIFICATION AND FUNCTIONS
}

\begin{abstract}
Summary. The article analyzes testing as one of the means of teaching the language. It is devoted to different types of testing. Different approaches to classifying tests are discussed. Ways of testing are suggested. Advantages and disadvantages of each type are discussed. All classifications of language tests have different theoretical and practical grounds. A practical approach to classifying tests is that on the basis of its purpose. We distinguish diagnostic, placement, achievement and proficiency testing. The most important for the teacher is the division of ways or forms of testing each having its advantages and disadvantages. The main types of testing include questions and answers, true/false, multiple-choice, gap-filling and completion, dictation, transformation, rewriting, translation, essay, error recognition, and word-formation. Each of them has certain restrictions as to which language skill it is supposed to test.
\end{abstract}

Keywords: test, testing, testee, evaluation, advantage, disadvantage.

Поплавська Л.Л., Островська О.М. Львівський національний університет імені Івана Франка

\section{ТЕСТУВАННЯ У ПРОЦЕСІ ВИКЛАДАННЯ ІНОЗЕМНОЇ МОВИ: КЛАСИФІКАЦІЯ ТА ФУНКЦЇ̈}

\begin{abstract}
Анотація. У статті аналізується тестовий контроль як невід'емний елемент і умова успішного засвоєння змісту навчання іноземної мови студентами. Поряд з безсумнівними достоїнствами тестової технології зазначено окремі негативні моменти. Тестування визнано наразі ефрективним засобом організації контролю у формуванні іншомовної комунікативної компетенщії студентів. Зазначено, що тестування в широкому сенсі може забезпечити успішну реалізацію мети і всіх фрункцій контролю, а також задовольнити вимоги, що висуваються до його якості. Тестовий контроль з іноземної залишаеться актуальним для дослідження проблеми. Зазначається, що головним завданням навчання іноземної мови є навчити студентів користуватися іноземною мовою як засобом спілкування в усіх видах мовленневої діяльності в різноманітних ситуаціях реального життя. Одним з аспектів у редормуванні освіти є впровадження нових методик оцінки навчальних досягнень студентів. Ефективність та надійність такої оцінки може реалізуватися шляхом тестового контролю. У статті розглянуто різні підходи до класифікації тестів. Найбільш доцільним є класифікація на підставі практичної мети такого тестового завдання, що дозволяе розрізняти тести оцінювання загального рівня мовленневої компетенції студентів, тести контролю поточної успішності, підсумкові тести тощо. Важливо усвідомлювати переваги та недоліки таких тестів у кожній конкретній навчальній ситуації. Регулярний контроль рівня знань студентів є важливою складовою процесу викладання іноземних мов. Використання різних типів тестових завдань дозволяе урізноманітнити навчальний процес і $€$ ефективним джерелом мотивації студентів до оволодіння іноземною мовою.
\end{abstract}

Ключові слова: тест, тестування, тестований, оцінювання, користь, недоліки.

Droblem statement. Testing remains an effective means of organizing the control of students' foreign language communication competence. Practice shows that testing in a broad sense can ensure the successful implementation of the goal and all control functions, as well as meet the requirements for its quality. Test control in a foreign language teaching and learning remains an important research problem. The main task of teaching a foreign language is to teach students to use a foreign language as a means of communication in all types of speech activities in various real-life situations. One of the aspects of the educational reform is introduce new methods of the academic assessment of the students' progress. The effectiveness and reliability of such an assessment can be achieved through test control.

Recent research and publications. Many works are devoted to studying the problem of testing in foreign language teaching, among the scholars who investigated the problem are O. Kvasova, O. Molokovych, S. Nikolayeva, O. Petrashchuk, J.Ch. Alderson, L. Bachman, D. Brown, F. Davidson, A. Davies, P. Skehan, and others. The theoretical principles that have been identified in these investigations constitute a fairly sound general theory of test control in foreign language learning. However, methodological approaches to foreign language testing need further investigation.

The purpose of this article is to review current methods of assessing the students' academic achievements through test control. The objective of the article is to determine the most effective methods of testing a foreign language.

Presentation of the main material. The necessity to know English is the one a person has to meet in any sphere of modern life. It is caused by the globalization and the role of English as the language of international communication. It is the requirement for being successful in production, technology, education, research, etc. It is an absolute necessity in business and politics. Therefore, the problems connected with different aspects of English teaching remain in the spotlight of the researchers' interests.

Testing is a specific aspect of teaching, as it has special purposes, causes completely different reaction of learners and teachers, and needs to have a special form. Moreover, nowadays, it is very topical, as passing some kind of proficiency test is often necessary for many professionals. 
P. Ur writes about formal and informal testing [8, p. 36]. She writes that tests in the classroom may be of the convenient type where the testees are told in advance what they need to know, what are the criteria are for success, and so on. But they may also be informal: a homework assignment may in fact function as a test if the teacher's main aim in giving it is to find out whether the learners have learned some language point or not; questions asked during the routine give-and-take of classroom interaction may serve the same purpose, as may some textbook exercises.

A. Hughes distinguishes direct and indirect testing, by which he means that the skill to be tested may be involved directly or indirectly [5, p. 14] Thus, when applying the direct testing the teacher will be interested in testing a particular skill, e.g.: if the aim of the test is to check listening comprehension, the students will be given a test that will check their listening skills, such as listening to the tape and doing the accompanying tasks. Such type of a test will not engage testing of other skills. Other characteristic feature of direct testing is its introducing real-life language through authentic tasks. Direct testing is task-oriented, effective and easy to manage if it tests such skills as writing or speaking. It could be explained by the fact that the tasks intended to check the skills mentioned above give us precise information about the learners' abilities. Moreover, we can maintain that when testing writing the teacher demands the students to write a certain task, such as an essay or reproduction, and it will be precisely the point the teacher will be intended to check.

In contrast, the indirect testing measures a skill through some other skill. It could mean the incorporation of various skills that are connected with each other, e.g.: listening and speaking skills. According to A. Hughes, indirect testing checkups the usage of the language in real-life situations. Moreover, it suits all situations; whereas direct testing is bound to certain tasks intended to check a certain skill [5, p. 15]. Learners are not constrained to one particular skill and a relevant exercise. They are free to elaborate all four skills; what is checked is their ability to operate with those skills and apply them in various, even unpredictable situations. This is the true indicator of the learner's real knowledge of the language. One possible drawback of this way of testing is certain difficulty in evaluating [5, p. 16].

A. Bynom discusses discrete-point and integrative testing. According to the scholar discrete point test is a language test that is meant to test a particular language item (e.g.: body parts vocabulary, active voice tenses, infinitive and gerund, etc.) [2] The basis of that type of tests is that we can test components of the language (grammar, vocabulary, pronunciation and spelling) and language skills (listening, reading, speaking and writing) separately. Having studied a grammar topic or new vocabulary, having practiced it a great deal, the teacher basically gives a test based on the covered material. This test usually includes the items that were studied and will never display anything else from a far different field. The same will concern the language skills; if the teacher's aim is to check reading skills, the other skills will be neglected. Notwithstanding, this type was and still remains to be the most gen- eral and acceptable type in schools of our country, for it is easy to design, it concerns a certain aspect of the language and is easy to score. A. Bynum thinks that a drawback of discrete point testing is that it tests only separate aspects, but does not show us the whole language competence [2].

Integrative test, on the other hand, intends to check several language skills and language components together or simultaneously. A. Hughes writes that the integrative tests display the learners' knowledge of grammar, vocabulary, spelling together, but not as separate skills or items [5, p. 8]. It seems that rather than discussing which type of testing should be used, it is better to incorporate both types of testing for effective evaluation of the students' true language abilities.

One general distinction between types of testing is mentioned in a number of sources by: J. Heaton, A. Hughes, A. Bynom, J. Harmer, P. Ur, and C. Weir. It is criterion-referenced, norm-referenced testing. Generally, criterion-referenced test is believed to measure the knowledge of the students according to set standards or criteria. This means that there will be certain criteria according to which the students will be assessed. There will be various criteria for different levels of the students' language knowledge. Here the aim of testing is not to compare the results of the students. It is connected with the learners' knowledge of the subject. As A. Hughes puts it, the criterion-referenced tests check the actual language abilities of the students, they distinguish the weak and strong points of the students, and the students either manage to pass the test or fail it [5, p. 16].

The other type of the opposition - norm-referenced test, measures the knowledge of the learner and compares it with the knowledge of another member of his/her group. The learner's score is compared with the scores of the other students. It is usually mentioned that this type of test does not show us what exactly the student knows [5, p. 16].

If we want to differentiate the tests on the basis of their exact purpose, we come to the distinction between diagnostic, placement, achievement, and proficiency testing [4-6; 9].

Diagnostic test is a test that is meant to display what the student knows and what he/she does not know, spot the strong and weak points. It is necessary when the students return from their summer holidays or if the students start a new course and the teacher is completely unfamiliar with the level of the group. Moreover, N. Underhill points out that apart from the above mentioned the most essential element of the diagnostic test is that the students should not feel depressed when the test is completed. Therefore, very often the teachers do not put any marks for the diagnostic test and sometimes even do not show the test to the learners if the students do not ask the teacher to return it [7, p. 14 ].

Placement test is a test that places the students at an appropriate level in a course. In other words, it will assist to put the student exactly in that group that responds his/her true abilities. J. Heaton writes that the following type of testing should be general and should purely focus on a vast range of topics of the language not on just specific one [4, p. 18]. Therefore, the placement test typically could be represented in the form of dictations, in- 
terviews, grammar tests, etc. Moreover, according to J. Heaton, the placement test should deal exactly with the language skills relevant to those that will be taught during a particular course. If our course includes development of writing skills required for politics, it is not appropriate to study writing required for medical purposes [4, p. 18].

Achievement test is a test, which measures a language someone has learned during a specific course, study or program. Here the progress is significant and, therefore, is the main point tested. Usually achievement tests are mainly given at definite times of the school year. Moreover, they could be extremely crucial for the students, for they are intended either to make the students pass or fail the test. Therefore, the test should be based directly on the objectives of the course. Achievement tests are meant to check the mastery of the material covered by the learners. They will be great helpers for the teacher's future work and will contribute a lot to the student's progress.

Proficiency test is a test, which measures how much of a language a person knows or has learnt. It is not bound to any curriculum or syllabus, but is intended to check the learners' language competence. In this test training is not the thing that is emphasized, but the language. 'Proficient' in the case of proficiency tests means possessing a certain ability of using the language according to an appropriate purpose. It denotes that the learner's language ability could be tested in various fields or subjects in order to check whether the learner could suit the demands of a specific field or not. Importantly, the proficiency tests are rather impartial; they are not testee-friendly.

There are various approaches to classifying the exact types of language tests. According to P. Ur they are as follows [8, p. 39-41]: 1) questions and answers tests or short answer tests; 2) true/false tests used to control the students' understanding of vocabulary/grammar content of a reading or listening passage; 3) multiple-choice tests are used checkup vocabulary, however, they can be useful in testing grammar, listening or reading skills [4, p. 79]; 4) gap-filling and completion tests deal with grammar or vocabulary; 5) matching tests usually checkup vocabulary; 6) tests in the form of dictation that according to $\mathrm{C}$. Weir make the students use the variety of skills: listening, reading, speaking and writing skills [9, p. 49]; 7) transformation tests deal with re-writing sentences, e.g. transforming sentences from Active into Passive voice [4, p. 32]; 8) rewriting tests deal with language transformation, they involve paraphrasing as well as transforming separate items; 9) translation tests that give the opportunity to check the whole spectrum of the students' language skills; 10) essay writing tests are highly appreciated by J. Heaton, who believes that the most suitable way to check the students' writing skills is essay writing [4, p. 31];

There are also ways of testing which have not been mentioned by P. Ur, but discussed by other scholars [4-5]. They are: error recognition tests when students are to recognize which word is wrong in a piece of writing and correct it; J. Heaton suggest supplying the students with incorrect sentences asking them to provide another, correct variant [4, p. 39]; word-formation tests frequently used in exams to know the students' ability to coin new words from verbs, adjectives from nouns by means of prefixes, suffixes and roots.

Conclusion. All classifications of language tests have different grounds, and are of interest from a more theoretical point of view. A more practical approach is the classification of tests on the basis of their purpose; it allows distinguishing diagnostic, placement, achievement and proficiency testing. The most important for the teacher is the division of ways or forms of testing each having its advantages and disadvantages. The main ways of testing include questions and answers, true/false, multiple-choice, gap-filling and completion, dictation, transformation, rewriting, translation, essay, error recognition, word-formation. Each of them has certain restrictions as to which language skill it is supposed to test.

Thus, testing is a necessary part of teaching, and may play a crucial role in the management of class. If well designed, tests will fulfill a number of functions: they will show the students' progress, or knowledge (depending on the test type), and show certain gaps which will help the teacher modify the syllabus, tests are a great source of motivation for the students, they help them develop learning skills, and they are among most effective means of teaching the language.

\section{References:}

1. Brown D. Teaching by principles: an interactive approach to language pedagogy. N.Y.: Pearson Education, 2001.253 p.

2. Bynom A. Testing: basic terms: basic terminology. URL: http://www.telus.net/linguisticsissues/testing.htm

3. Harmer J. The practice of English language teaching. Pearson Education Ltd., 2001. 249 p.

4. Heaton J. Classroom Testing. Longman, 1990. 128 p.

5. Hughes A. Testing for language Teachers. Cambridge: CUP, 2002. 264 p.

6. Thompson M. Putting students to the tests. Forum. 2001. № 20. July. P. 17-27.

7. Underhill N. Testing Spoken Language. Cambridge: CUP, 1987. 128 p.

8. Ur P. A Course in Language Teaching. Practice and Theory. Cambridge: CUP, 1991. 388 p.

9. Weir C. Communicative Language Testing. Prentice Hall, 1991. 353 p. 